\title{
Shallow crystallization of eruptive magma inferred from volcanic ash microtextures: a case study of the 2018 eruption of Shinmoedake volcano, Japan
}

\author{
Keiko Matsumoto $^{1}$ (D) Nobuo Geshi $^{1}$
}

Received: 20 November 2020 / Accepted: 8 March 2021 / Published online: 10 April 2021

(c) The Author(s) 2021

\begin{abstract}
The occurrence of groundmass crystals reveals the shallow conduit process of magmas, which affects the behavior of eruptions. Here, we analyzed groundmass microtextures of ash samples from the 2018 eruption of Shinmoedake volcano, Japan, to evaluate the change of magma ascent conditions during the eruption sequence. The eruptive activity changed from ash venting (Phase 1: March 1-6) to lava effusion with continuous ash-laden plumes (Phase 2: March 6-9) and then shifted to Vulcanian explosions (Phase 3: March 10-April 5). Non-juvenile particles were abundant in Phase 1, whereas juvenile particles were dominant in Phases 2 and 3. Vesicular juvenile particles were more abundant in Phase 2 than Phase 3. The lower microlite crystallinity and groundmass $\mathrm{SiO}_{2}$ concentrations of the vesicular particles indicate that they were sourced from magma that ascended rapidly. Abundant nanolites were observed in the black interstitial glass of juvenile particles under an optical microscope, whereas few nanolites were observed in the transparent ones. The presence of nanolites can be explained by the dehydration of silicate melt, as well as cooling and oxidation between fragmentation and quenching. Temporal changes in the ash componentry show that the eruption activity started from the erosion of the pre-existing vent plug (Phase 1), shifted to the simultaneous eruption of bubble-bearing and outgassed magmas (Phase 2), and concluded with explosions of the stagnant lava (Phase 3), thereby demonstrating the sequence of vent opening and extrusion and stagnation of magma. Therefore, ash microtextures are valuable for monitoring the shallow conduit process of eruptive magma.
\end{abstract}

Keywords Volcanic ash $\cdot$ Glass $\cdot$ Crystallization $\cdot$ Microtexture $\cdot$ Shinmoedake volcano

\section{Introduction}

Numerous volcanic eruptions show temporal changes in eruption characteristics, such as magma eruption rate and explosivity (e.g., Wright et al. 2012; Kozono et al. 2013; Schipper et al. 2013). Predicting the temporal variation of volcanic eruptions based on the monitoring of volcanic activities is one of the most important issues for volcano hazard assessment and risk mitigation. Microtextures of volcanic ash are a useful tool for monitoring the activities of eruptions because they record the magma ascending and eruption conditions of diverse eruption styles (e.g.,

Editorial responsibility: J. Eychenne

Keiko Matsumoto

k.matsumoto@aist.go.jp

1 Geological Survey of Japan, AIST, Central 7, 1-1-1 Higashi, Tsukuba, Ibaraki 305-8567, Japan
Taddeucci et al. 2004; Miwa et al. 2013; D'Oriano et al. 2014; Deardorff and Cashman 2017). Complex ascending paths of magma in the volcanic conduit are captured in the diverse occurrence of groundmass crystals as their crystallization kinetics are changed by cooling, decompression, and degassing of magma in the conduit (Hammer and Rutherford 2002; Shea and Hammer 2013). By distinguishing the morphological and textural characteristics of the volcanic ash particles and quantifying the ash componentry, the magma ascent, degassing, and fragmentation processes can be reconstructed (Wright et al. 2012; Leibrandt and Le Pennec 2015).

The crystallization kinetics of groundmass microlites have been studied using experimental approaches (Hammer and Rutherford 2002; Brugger and Hammer 2010; Cashman 2020 ) and by the analysis of natural samples (Castro and Gardner 2008; Wright et al. 2012) to estimate the ascent rate of magmas. In addition, crystallization of nanolites (hereafter, groundmass crystals with ca. $<1 \mu \mathrm{m}$ in width; D'Oriano 
et al. 2014; Mujin and Nakamura 2014; Mujin et al. 2017) may control eruption behavior by increasing magma viscosity (Di Genova et al. 2017, 2020) and the promotion of late-stage bubble nucleation (Cáceres et al. 2020) during magma ascent. Although comparisons of such diverse groundmass microtextures have been made among natural samples from typical eruption styles, detailed descriptions of ash fragments during ongoing eruptions and their comparison between transition phases are lacking. In particular, few studies have elucidated the relationship between microtextures of erupted materials and eruption sequence described by geophysical and surface observations (e.g., Miwa et al. 2009; Matsumoto et al. 2013; Miyabuchi and Hara 2019).

The 1-month activity of the 2018 eruption of Shinmoedake volcano, Kyushu, Japan, exhibited numerous variations in eruption styles throughout its activity (Yamada et al. 2019), providing a good opportunity for evaluating transitions in eruption behavior via ash monitoring. Here, we examine the temporal change of the groundmass microtextures during the 2018 eruption to investigate magma ascent processes at a shallow level, which are essentially undetectable by the geophysical monitoring system.

\section{Volcanological background and activity of the 2018 eruption of Shinmoedake}

Shinmoedake is one of the active centers of the Kirishima volcanic group located in Kyushu, Japan (Fig. 1). Shinmoedake is an andesitic stratovolcano that has produced several sub-Plinian eruptions in the Holocene (eruptions of the Setao Pumice fall deposit around $10.4 \mathrm{cal} \mathrm{ka}$, Maeyama pumice fall deposit around $5.6 \mathrm{cal} \mathrm{ka}$, Kyoho pumice fall deposit in 1716-1717 CE, and pumice fall deposit in
2011 CE; Imura and Kobayashi 1991, 2001; Okuno 2002; Miyabuchi et al. 2013; Nakada et al. 2013).

Leading up to 2011, Shinmoedake resumed eruptive activity with a small phreatic eruption on August 22, 2008, after a dormant period since minor ash venting in 1991 (Geshi et al. 2010). Three pulses of sub-Plinian eruptions and subsequent lava effusion and intermittent Vulcanian explosions occurred in January 2011. A total of $0.02 \mathrm{~km}^{3}$ dense rock equivalent (DRE) of andesitic magma erupted as a pumice fall deposit and crater-fill lava flow (Miyabuchi et al. 2013). Minor ash venting activities also occurred between October 11 and October 17, 2017.

The 2018 eruption of Shinmoedake started at around 11 am JST (Japan Standard Time, UT+09:00) on March 1, and lasted until June 27 (Fig. 2). The following descriptions of the 2018 eruptions are mainly based on reports from the Japan Meteorological Agency (JMA, https://www.jma.go. $\mathrm{jp} / \mathrm{jma} / \mathrm{indexe}$.html). The eruption can be divided into three phases based on the type of activity.

Phase 1 (March 1 to March 6) was characterized by ash venting from the east vent opened inside the 2011 lava field that covered the floor of the Shinmoedake summit crater during the 2017 activity. Intermittent ash venting continued until the afternoon of March 5, with increasing eruption intensity.

Phase 2 (from March 6 to March 9) was characterized by lava effusion with frequent small explosions. Lava effusion was recognized in the morning of March 6, from the east vent in the 2011 lava field. A rapid tilt change and an increase in the amplitude of the seismic signal on March 6 (Yamada et al. 2019) suggest the start of magma effusion. The lava spread over the 2011 lava field and buried the Shinmoedake summit crater. The total volume of the lava flow is estimated to be $1.5 \times 10^{7} \mathrm{~m}^{3}$ based on geographical
Fig. 1 a Map showing the location of Kirishima volcanic group, Japan. b Location of Shinmoedake volcano within the Kirishima volcanic group. The slope gradation map was drawn by the Geospatial Information Authority of Japan (2020)
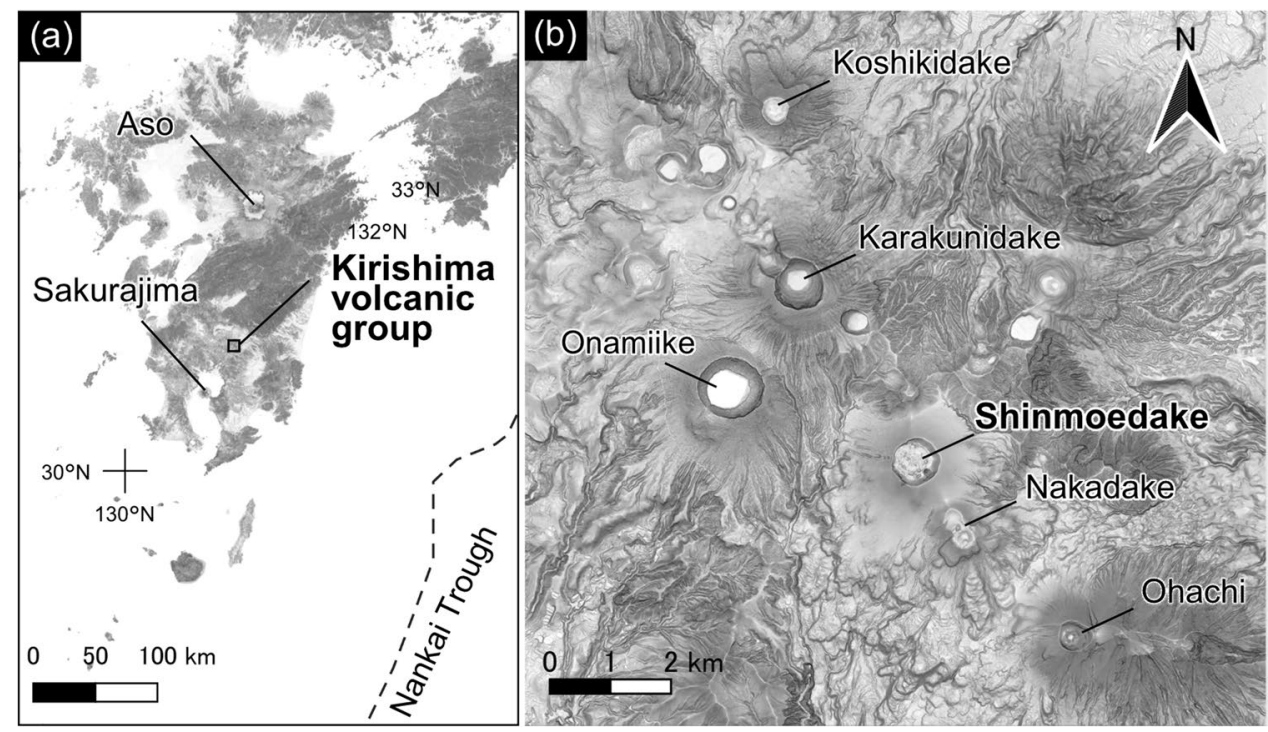


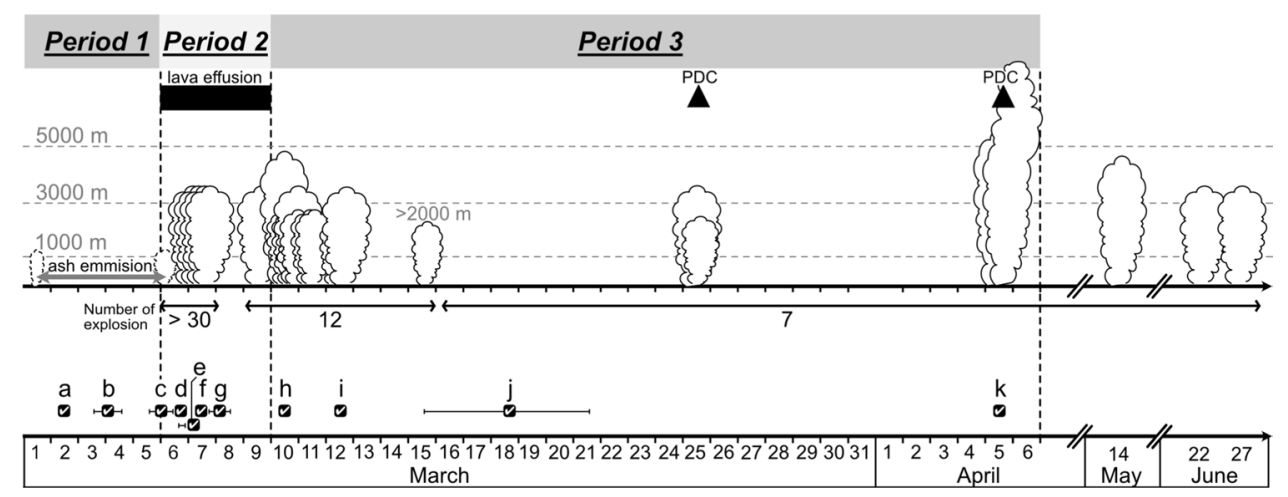

Fig. 2 Activity of the 2018 eruption of Shinmoedake volcano, Japan. Schematic eruption cloud icons indicate events of explosive eruptions, with sizes indicative of ash plume maximum heights above vent, which were measured via visual observation by the Japan Meteorological Agency (JMA). Filled box corresponds to the phase of lava

observations (Chiba et al. 2018). Simultaneous with the lava effusion, continuous vigorous ash emission occurred. The ash plumes in the afternoon of March 6 were generated from the middle of the new lava and the north side of the 2011 lava field. The ash-emitting activity became more explosive from the afternoon of March 6. At least 30 explosive events were counted between March 6 and 7 during the lava flow effusion. The maximum height of the eruption column reached $\sim 3 \mathrm{~km}$ above the crater, based on visual observation. The eruptions between the evening of March 6 and the morning of March 7 produced pumiceous lapilli, which have andesitic whole-rock compositions with $\sim 58 \mathrm{wt} \% \mathrm{SiO}_{2}$. The lava flow buried the summit crater of Shinmoedake and started outflowing from the NW rim of the crater on March 9. Lava effusion ceased around March 9, judging from the cessation of the growth of the lava flow and the termination of the rapid tilt change since March 6 (Yamada et al. 2019).

Phase 3 (from March 10 to June 27, the end of the eruption) was characterized by intermittent Vulcanian explosions. The interval between the Vulcanian explosions lengthened over time. JMA reported 12 Vulcanian explosions (JMA criteria; the number is based on the event counting of supply. Filled triangles mark the events of explosive eruption with pyroclastic density currents (PDC). Check boxes and bars correspond to the sampling period of analyzed ash samples in Table 1. Activity information is based on the report by JMA

ejected ballistics $>1 \mathrm{~km}$ from the crater, or eruption cloud rise $>3 \mathrm{~km}$ above the crater) between March 9 and 15, whereas only seven explosions were reported from March 16 to June 27. The height of the eruption column also increased during this period. The Vulcanian explosions between March 9 and 15 produced eruption columns up to $4.5 \mathrm{~km}$ above the crater. The explosion on April 5 occurred at the center of the lava flow, and the eruption column reached $8 \mathrm{~km}$ above the crater. Many ballistic blocks were dispersed within an area of $2 \mathrm{~km}$ from the summit during these explosions. Pyroclastic density currents were observed on March 25 and April 5.

\section{Sample collection and analytical methods}

Eleven representative samples are selected for the component analysis of the ash particles (Table 1, Fig. 2). Two, five, and four samples were selected from the products of Phase 1, Phase 2, and Phase 3, respectively. The samples were collected by researchers from the Geological Survey of Japan (GSJ) and JMA. Details of the sampling date and locations are shown in Table 1. For whole-rock chemical

Table 1 Sampling list of the analyzed volcanic ash from the 2018 eruption of Shinmoedake volcano

\begin{tabular}{cccccccccc}
\hline & Name Eruption phase & $\begin{array}{c}\text { Eruption date } \\
\text { (month/day) }\end{array}$ & $\begin{array}{c}\text { Sampling duration } \\
\text { (month/day) }\end{array}$ & $\begin{array}{c}\text { Distance and direction from } \\
\text { the crater }\end{array}$ & Type & $\begin{array}{c}\text { Sampling } \\
\text { method }\end{array}$ & Samples collected by & $\begin{array}{c}\text { Particle size used for } \\
\text { component analysis }\end{array}$ & $\begin{array}{c}\text { Number of particles for } \\
\text { component analysis } \\
\text { (without crystal } \\
\text { fragments }\end{array}$ \\
\hline \hline
\end{tabular}


compositions, two gray pumice lapilli, two black pumice lapilli, and two black dense fragments of lapilli size were collected from the surface layer at the rim of the crater. Based on the wind direction and the dispersive area of ash from March 6 to March 7, the pumice lapilli and dense fragments were inferred to be the juvenile products of the 2018 eruptions.

To investigate the surface and internal textures of ash particles, ash samples (medium to fine-size) were washed in distilled water for a few minutes using an ultrasonic cleaner to remove adhering fine (silt-size) particles. After drying at $100{ }^{\circ} \mathrm{C}$, the particles were dry-sieved into several classes of grain size $(63-125,125-250$, and $250-500 \mu \mathrm{m})$ using metal meshes.

Optical observation and component analysis of ash particles were conducted with all samples using an optical binocular microscope and optical digital microscopes (KEYENCE VHX-2000, GSJ; VHX-7000, Nuclear Regulation Authority, Japan). We selected particles between 250 and $500 \mu \mathrm{m}$ in diameter to maximize groundmass area for textural and chemical analyses. For samples with insufficient amounts of particles with sizes of $250-500 \mu \mathrm{m}$, particles with sizes of 125-250 $\mu \mathrm{m}$ were used for observation instead. More than 200 particles are used for componentry analysis (Table 1 and Table S3).

To investigate the internal texture and chemical composition of ash, 25 particles each of March 3-4 (18-K6), March 7 (18-K15), March 10 (18-K30), and April 5 (18-K54a) samples were embedded in epoxy resin and polished to expose their interiors. The internal micro-textures of the ash particles were observed via scanning electron microscopy (SEM) with a tungsten filament (JEOL JSM-6610LV, JSM-6480) and field emission scanning electron microscopy (FE-SEM; JEOL JXA-8530F Plus) at GSJ. The chemical compositions of the bulk groundmass (microlite + interstitial glass) and the interstitial glass of each ash particle are measured for 5-7 representative particles of each ash samples via energy dispersive X-ray spectroscopy (EDS) using SEM (Table S2). The conditions for analysis were an acceleration voltage of $15 \mathrm{kV}$, beam current of $1 \mathrm{nA}$, and a live counting time of $50 \mathrm{~s}$. Three to four areas of interstitial glass $\left(\sim 20-80 \mu \mathrm{m}^{2}\right)$ per particle were undertaken for the analysis of interstitial glass. For this area size, the amount of $\mathrm{Na}$ is underestimated by $10 \%$ (Geshi et al. 2017). Water concentrations in interstitial glasses were determined using stoichiometric balance between the oxygen and cation elements (Geshi et al. 2017). Detailed method and data evaluation procedures are in Supplementary Information 1. Groundmass crystallinities were calculated from the concentration difference of the $\mathrm{K}_{2} \mathrm{O}$ component between the bulk groundmass and interstitial glass of each ash particle, assuming that $\mathrm{K}_{2} \mathrm{O}$ is an incompatible component (Nakada and Motomura 1999, Wright et al. 2012).
To identify Fe-oxide mineral phases, Raman spectroscopy was utilized with a JASCO NRS-5500 at GSJ. Raman spectra were acquired using a $457 \mathrm{~nm}$ excitation laser, 1800 grooves $/ \mathrm{mm}$ grating, and a $\times 100$ objective. The laser power on the sample surface was measured to be $1.3 \mathrm{~mW}$. Acquisition time was $60 \mathrm{~s}$, and repetition was $60 \mathrm{~s}$ and three times.

For comparison, whole-rock chemical compositions were acquired for pumice clasts and dense fragments. The chemical compositions were determined by wavelength-dispersive X-ray fluorescence spectrometry (XRF; PANalytical Axios Advanced) at GSJ. The sample preparation and analytical methods followed those of Geshi et al. (2020).

\section{Results}

\section{Classification of ash particles}

The collected ash samples consist of various types of rock fragment particles. We classified ash particles into four "juvenile" groups and three "non-juvenile" groups, based on the occurrence of secondary minerals, and on the texture and color of their groundmass (Fig. 3). Additionally, fragments of volcanic crystals were also found in all ash samples.

We regard the ash particles exhibiting a fresh appearance with glossy surfaces as juvenile particles (Fig. 4). No secondary minerals were found in these ash particles. The juvenile ash particles are subdivided into A1, A2, B1, and B2 based on the vesicularity and color of their groundmass. The particles of Group A are characterized by their highly vesicular groundmass (Fig. 4a and b). Group B particles are characterized by their very low vesicular groundmass (Fig. 4c and d). The ash particles of A1 and B1 have a glassy groundmass consisting of transparent and colorless glass. The ash particles of A2 and B2 have a cryptocrystalline groundmass with black to dark brown color and low transparency.

Ash particles characterized by the presence of secondary minerals are classified as $\mathrm{C} 1$ and $\mathrm{C} 2$, based on the color of particles and the assemblage of secondary minerals (Fig. 5a and b). We regard these as "non-juvenile particles" derived from the wall of the conduit and vent.

Ash particles with less glossy surfaces, extremely low vesicularity, and variable microlite and nanolite crystallinity are classified as C3 (Fig. 5c). Although their appearances are similar to B2 under an optical microscope, they can be distinguished by their highly variable internal textures and relatively large ( 70 to 470 -nm wide) sub-micrometer crystals in the interstices of microlites. We regard C3 ash as "non-juvenile particles" that are likely derived from the juvenile materials of past eruptions. 
Fig. 3 Flowchart of ash particle type identification from the 2018 eruption of Shinmoedake

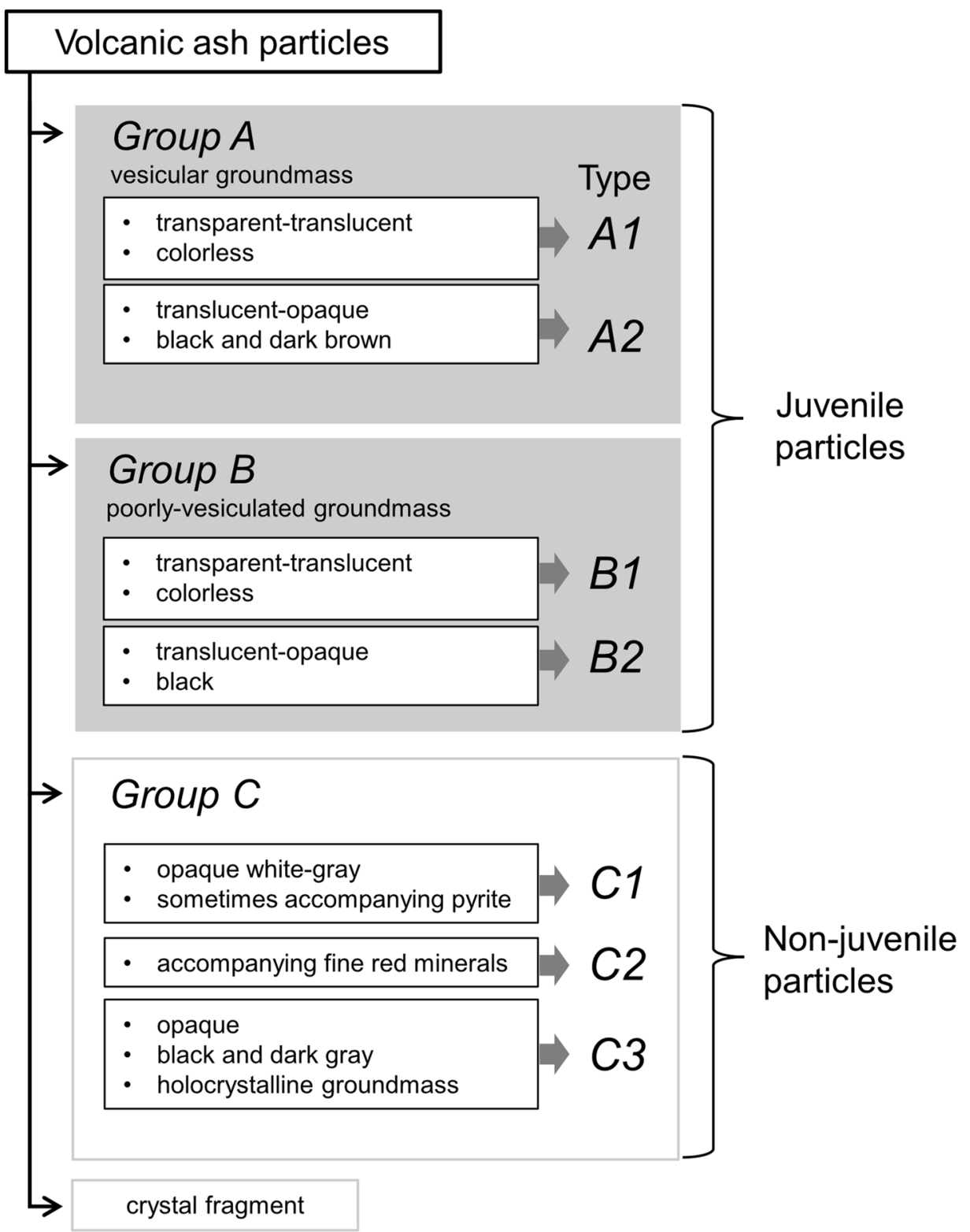

\section{Chemical composition of groundmass glass}

Groundmass glass (i.e., matrix glass between microlites) compositions between Group A and Group B differ markedly. Group $\mathrm{A}$ have $\mathrm{SiO}_{2}$ contents ranging from 65.7-70.6 wt\%, whereas Group B contains higher $\mathrm{SiO}_{2}$ contents with 72.2-80.0 wt\%, independent of the date of eruption (Fig. 6; Table S2). Water contents of groundmass glass (including nanolites when present) are estimated to be $<$ 0.4 and $<1.1 \mathrm{wt} \%$ for Group A and Group B, respectively (Table S2).

\section{Microtexture of juvenile ash particles}

Here, we describe the groundmass texture of the juvenile particles. Although the juvenile ash particles are subdivided into A1, A2, B1, and B2 based on their vesicularity and presence/absence of nanolites, they exhibit similar petrological characteristics. They contain plagioclase, orthopyroxene, clinopyroxene, and magnetite crystals as microlites. We regard crystals larger than $1 \mu \mathrm{m}$ and smaller than $\sim 100 \mu \mathrm{m}$ as microlites. The groundmass consists of microlite crystals and interstitial glass. Some interstitial "glass" patches are 
Fig. 4 Types of juvenile particles identified in this study. (ad) Optical microscope images of the representative particles (left column) and internal texture (right column). (e-h) Back scattered electron (BSE) images of particles indicated in the right column of (a-d). No nanolite crystals are observed in the interstitial melt of A1 and B1 particles (right column in e and $\mathrm{g}$ ), while they are detected in $\mathrm{A} 2$ and $\mathrm{B} 2$ particles (right column in $\mathbf{g}$ and $\mathbf{h}$ ). Widths of nanolite crystals are written in (f) and (h)

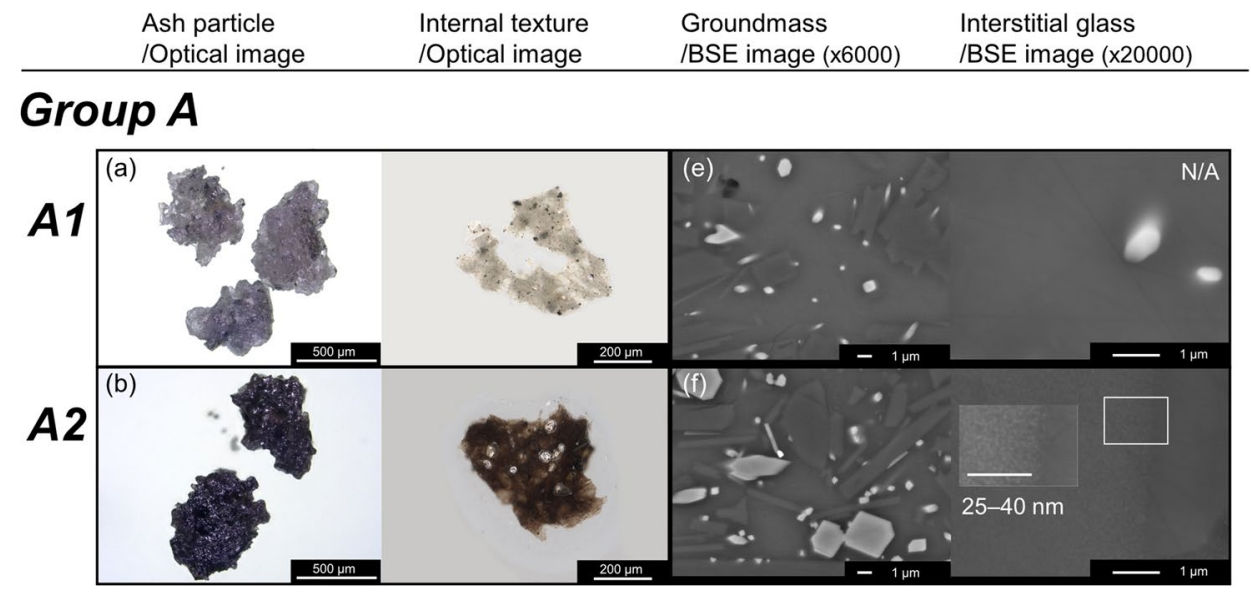

\section{Group B}

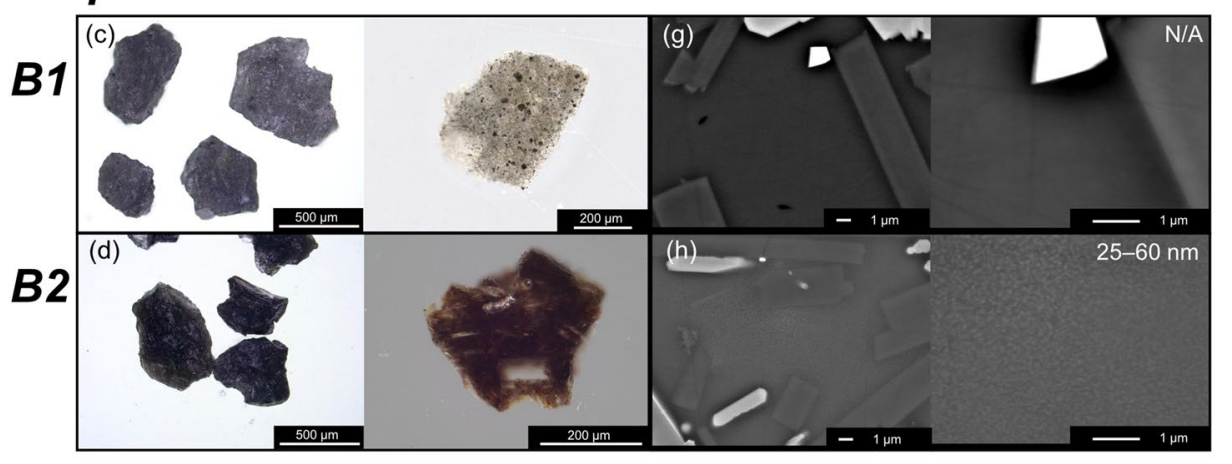

cryptocrystalline owing to the presence of nanolites that are less than $1 \mu \mathrm{m}$ in diameter.

A1 particles are characterized by high vesicularity and transparent to translucent interstitial glass that is colorless (Fig. 4a). Orthopyroxene microlites commonly display reverse-compositional zoning rims of 3-4 $\mu \mathrm{m}$ in width. The microlite crystallinities vary from 29.1 to $31.9 \mathrm{wt} \%$ (hereafter, representing the average of each particle). The interstitial glass shows homogeneous backscattered electron (BSE) images, and no nanolites are detected via high magnification (up to $\times 20000$ ) observations made using FE-SEM (Fig. 4e). The representative $\mathrm{SiO}_{2}$ content of interstitial glass is $68.5-70.0 \mathrm{wt} \%$ (Fig. 6).

A2 particles are characterized by translucent to opaque, dark-colored groundmass glass (Fig. 4b). The vesicularity of the groundmass glass is similar to that of the A1 particles. Nanolite crystals less than $30-50 \mathrm{~nm}$ in width are commonly found in the interstitial glass, although the interstitial glass is apparently uniform under the observation of low-magnification BSE images (Fig. 4f). The color of the groundmass gradually varies from colorless (A1) to black (A2), which may reflect the degree of nanolite crystallinity because visible light is scattered by crystals smaller than its wavelength ( 400-780 nm). Orthopyroxene microlites commonly display reverse zoning rims of 3-4 $\mu \mathrm{m}$ in width.
The volume fractions of the microlites are between 18.2 and $37.4 \mathrm{wt} \%$, and chemical composition of interstitial glass is between 65.7 and $70.6 \mathrm{wt} \%$ of $\mathrm{SiO}_{2}$ (Fig. 6; intercrystalline glass including nanolites), which are similar to those of the A1 particles.

B1 particles are characterized by poor vesicularity and colorless to pale-colored groundmasses (Fig. 4c). Some orthopyroxene microlite crystals show reverse-compositional zoning on their outer $3-4-\mu \mathrm{m}$ wide rims, which also often display thin $(<2 \mu \mathrm{m})$ Ca-rich domains on their rims that appear to be pigeonite based on the EDS analysis. The average crystallinities of these particles range from 36.0 to $56.5 \mathrm{wt} \%$. The interstitial glass is homogeneous in BSE images, and no nanolites are indicated under the high magnification (up to $\times 20000$ ) observations via FE-SEM (Fig. 4g). The $\mathrm{SiO}_{2}$ contents of the groundmass interstitial glass range from 73.5 to $80.0 \mathrm{wt} \%$ (Fig. 6).

B2 particles are characterized by poor vesicularity, opaque, and black to dark gray-colored groundmasses (Fig. 4d). Nanolites ranging from $\sim 30$ to $140 \mathrm{~nm}$ in size are present in the interstitial glass (Fig. 4h), which presumably cause the opaque color. They do not form an interface with microlites but tend to be distributed between plagioclase microlites, rather than pyroxenes and magnetite. The average microlite crystallinities (excluding nanolites) range from 
Fig. 5 Typical non-juvenile particles observed in this study. (ac) Optical microscope images of representative particles (left column) and internal texture (right column). (d, e, g) Back scattered electron (BSE) images of particles in right column of $(\mathbf{a}-\mathbf{c})$. Widths of nanolite crystals are written in (g). (f) Raman spectrum acquired on a spot in a typical accessory particle which exhibited red color under optical microscope. The Raman bands represent hematite. Bright whiskers (white arrow) on pyroxene microlite are observed in the analyzed spot
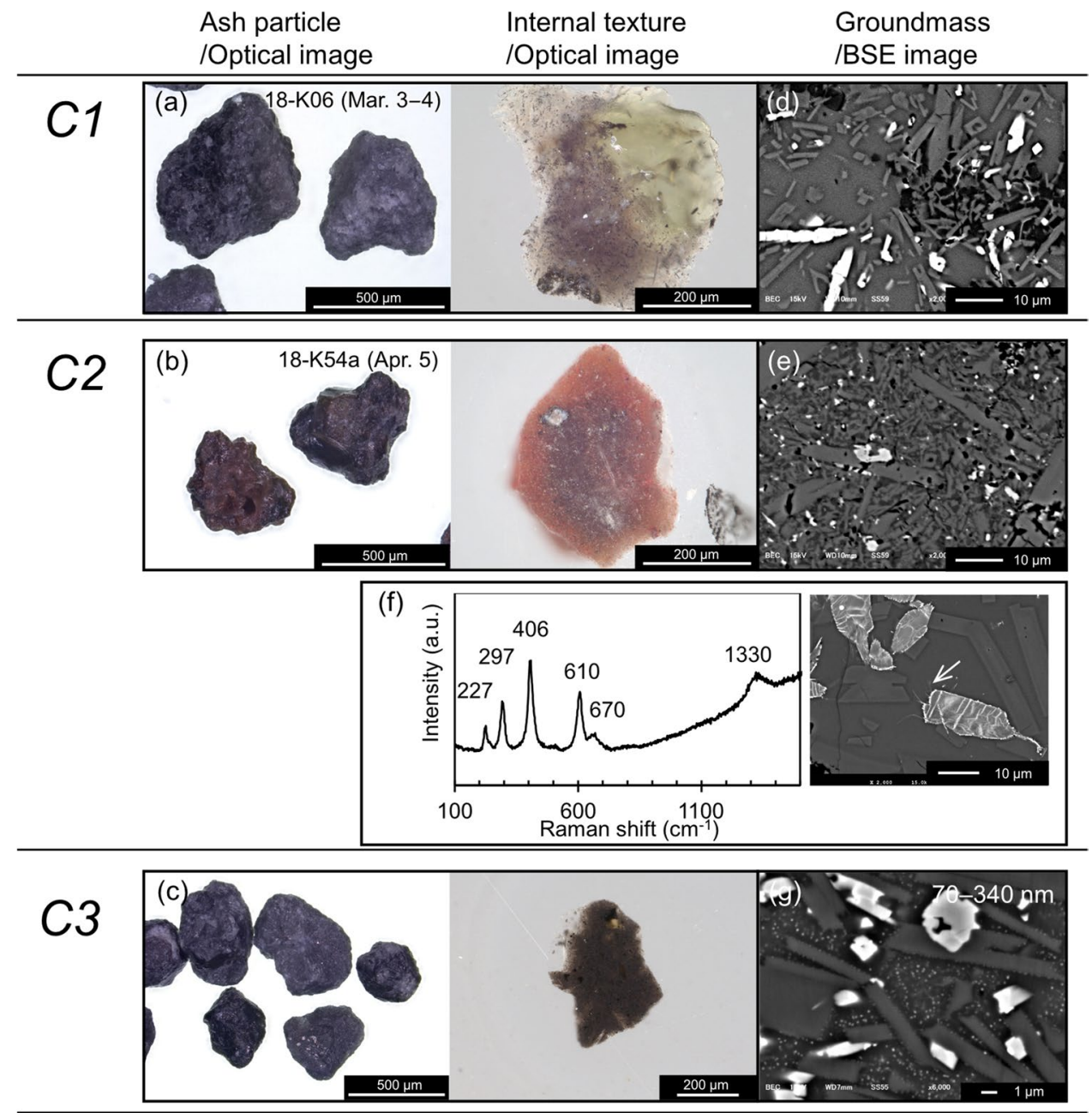

24.1 to $45.9 \mathrm{wt} \%$ for $\mathrm{B} 2$ particles. The $\mathrm{SiO}_{2}$ content of the groundmass interstitial melt (including nanolites) in typical particles ranges from 70.5 to $77.4 \mathrm{wt} \%$ (Fig. 6).

\section{Microtexture of non-juvenile particles}

Non-juvenile particles (C1-C3) contain different types of secondary minerals (Fig. 5). The $\mathrm{C} 1$ particles are characterized by the presence of white opaque mineral particles and yellowish metallic particles, even though the $\mathrm{C} 1$ particles preserve their original volcanic rock textures (Fig. 5a). The secondary minerals found in $\mathrm{C} 1$ particles are silica minerals and pyrite, based on EDS analysis. C1 particles are characterized by sub-angular to rounded shapes (Fig. 5a), with several brittle cracks truncating both crystals and groundmass glass. Some brittle cracks are filled with secondary minerals. The groundmass of the original volcanic rocks contains microlite crystals of plagioclase, pyroxene, and Fe-Ti oxides.

C2 particles are distinguished as fine red mineral grains that can be observed under an optical microscope (Fig. 5b). Ash particles that exhibited a red color in some parts of the particle are classified as C2, regardless of the color or texture of the other parts (Fig. 5b). Most of the host particles were dense and bubble-bearing black particles. In some particles, both orthopyroxene and clinopyroxene microlite crystals exhibit breakdown textures of bright lamellae under BSE images (Fig. 5f). The crystal margins of pyroxenes with breakdown exhibited a red color under an optical microscope. They have small bright crystals on their rim, which are sometimes accompanied by bright whiskers. Although the bright crystals are difficult to analyze via SEM-EDS due to their size, the possible presence of Fe oxide is indicated via Raman spectroscopy (Fig. 5f). The Raman bands at $220, \sim 290, \sim 400$, and $1300 \mathrm{~cm}^{-1}$ indicate that the bright whiskers are hematite. As the stability limit of hematite exhibits a $\sim$-log units higher $\mathrm{fO}_{2}$ than that of typical arcrelated andesitic magmas (Matsumoto and Nakamura 2017), the presence of hematite is indicative of the oxidation of ash particles by air.

C3 particles, with their dense groundmass, opaqueness, and black to dark gray color, are similar in appearance to B2 particles; however, they can be distinguished by the presence 

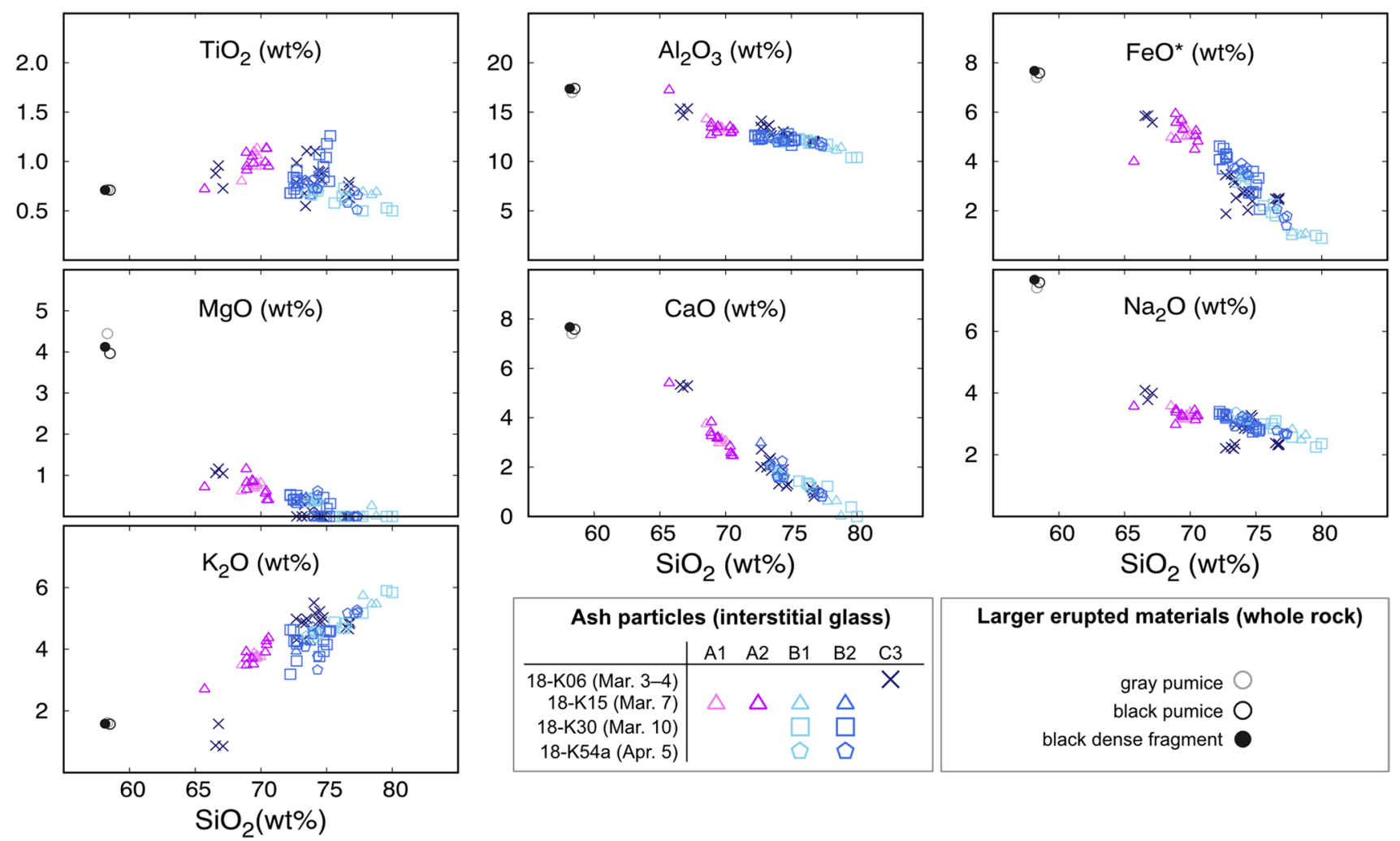

\begin{tabular}{|r|ccccc|}
\hline \multicolumn{6}{|c|}{ Ash particles (interstitial glass) } \\
& A1 & A2 & B1 & B2 & C3 \\
\hline 18-K06 (Mar. 3-4) & & & & & $\times$ \\
18-K15 (Mar. 7) & $\triangle$ & $\Delta$ & $\triangle$ & $\Delta$ \\
18-K30 (Mar. 10) & & & $\square$ & $\square$ \\
18-K54a (Apr. 5) & & & & $\square$ & \\
\hline
\end{tabular}

Larger erupted materials (whole rock)

gray pumice $\bigcirc$

black pumice $\mathrm{O}$

black dense fragment

Fig. $6 \mathrm{SiO}_{2}$ variation diagrams of groundmass interstitial glass of juvenile particles (i.e., the groundmass excluding phenocrysts and microlites but may include nanolites) from the 2018 eruption of Shinmoedake. Whole rock compositions of the 2018 erupted materials are also indicated. Juvenile particles are divided into less silicic $\left(\mathrm{SiO}_{2}=\right.$

of larger nanolites $(\sim 70-470 \mathrm{~nm}$ in width) in the groundmass (Fig. 5c and g). The particles commonly comprise plagioclase, orthopyroxene, clinopyroxene, and magnetite as microlite crystals, but the shapes and abundances of orthopyroxene and clinopyroxene microlites are highly variable among particles. Moreover, brittle cracks passing through microlite crystals and groundmass glass were commonly observed.

\section{Temporal change of ash components}

Figure 7 shows the temporal changes in the abundance of each type of ash particle during the 2018 eruption. Note that the following analysis excludes fragments of crystals that occupy 15-25 vol.\% of each sample.

The volcanic ash samples for Phase 1 mainly comprised B2, C1, and C3 particles. C1 particles included approximately half of the ash particles in Phase 1. Vesicular particles (A1 and A2) and particles with transparent interstitial glass (A1 and B1) were rarely found in the volcanic ash of Phase 1.

The volcanic ash samples collected for Phase 2 were characterized by the presence of vesicular juvenile particles (A1 and A2). At the beginning of Phase 2 (18-K11; March 5-6),
65.7-70.5 wt\%) and more silicic (72.2-80.0 wt\%) groups. Vesicular particles (A1 and A2) and poorly vesicular particles (B1 and B2) correspond to less silicic and more silicic groups, respectively, which are independent of eruption date. Note that the concentration of $\mathrm{Na}$ is probably underestimated (Supplementary Information 1)

poorly vesiculated particles (B1 and B2) occupied more than $70 \%$ of the samples. The component proportions of vesicular particles (Group A) increase from 2.3\% for March 5-6 (18$\mathrm{K} 11)$ to reach their maximum at $79.2 \%$ on March 7 (18-K15) and decreased to $9.2 \%$ from the evening of March 7-March 8 (18-K19). Correspondingly, the proportions of poorly vesiculated particles (Group B) that erupted during Phase 2 varied relative to the abundances of Group A particles. Populations of white-to-gray particles (C1) are notably low compared with the samples for Phase 1.

The ash samples for Phase 3 were predominantly comprised of poorly vesiculated particles (Group B) and redcolored particles (C2). Dense gray-to-black particles with sub-micron crystals (C3) were also observed in the ash erupted on March 15-21 and April 5.

\section{Discussion}

\section{Crystallization variation of juvenile particles}

Variations in the microtextural features and chemical compositions of groundmass glass among the juvenile particles 
Fig. 7 Time-sequenced component proportions of ash particles collected during the 2018 eruption of Shinmoedake. Number of analyzed particles and the grain sizes are indicated on the right side. Note that the grain sizes used are not all in the same range

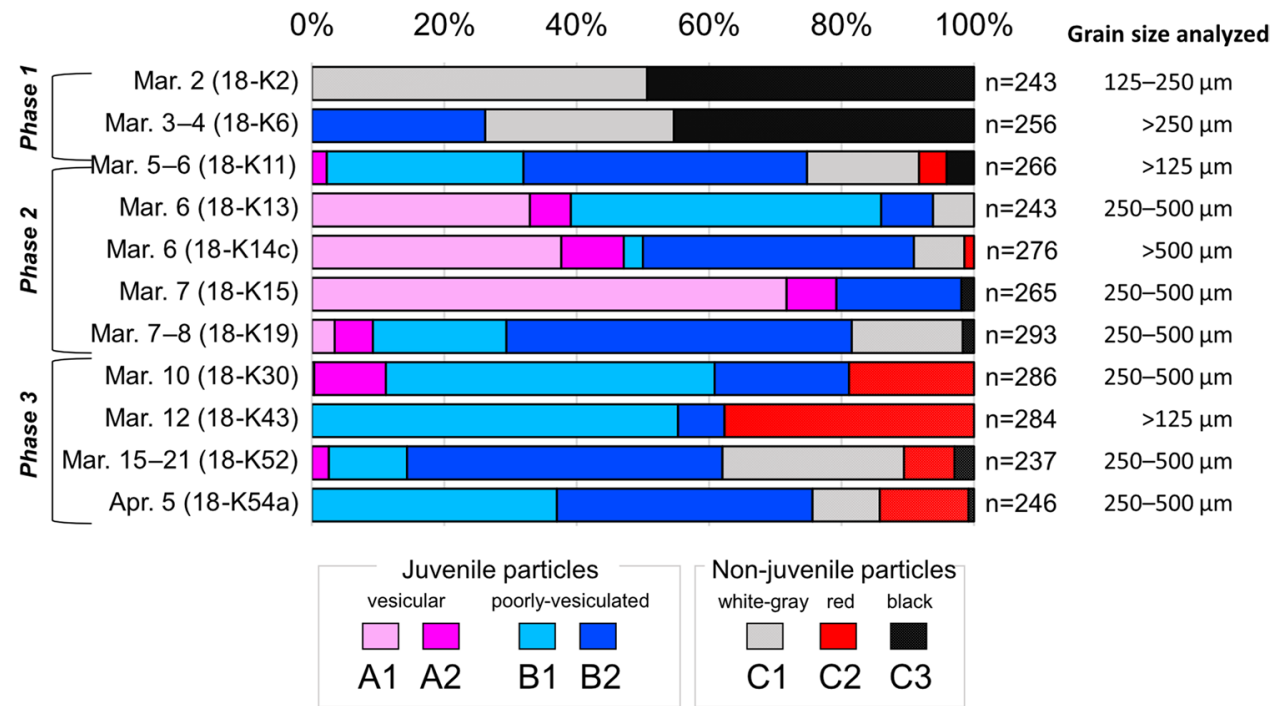

during ascent is common and the magmas may be nearly isothermal (Hammer and Rutherford 2002).

Figure 8 shows the relationship between the solubility curve of water in the silicate melt and the change in water content in the silicate melt during decompression. Assuming that a magma (i.e., silicate melt containing phenocrysts) starts to ascend with a certain content of water, the water content of the melt (i.e., liquid magma without phenocrysts) exceeds the saturated water content at $\mathrm{P} 1$ as the pressure decreases. The supersaturated melt maintains its water content under metastable conditions until dehydration of the melt occurs (P2). When the dehydration starts at pressure $\mathrm{P} 2$, the water content in the melt decreases and the liquidus temperature $\left(\mathrm{T}_{\text {liq }}\right)$ of the crystals increases accordingly. The rise of the liquidus temperature due to decompressiondehydration produces a rapid increase of "effective undercooling $(\Delta \mathrm{T})$ ". Depending on the undercooling of silicate melt, either nucleation or crystal growth can control the rate of bulk phase transformation from liquid to solid (Hammer and Rutherford 2002). Nucleation rate peaks at higher $\Delta \mathrm{T}$ values, as a high-energy barrier is required for nucleation due to the surface free energy.

In the first step, such an increase in $\Delta \mathrm{T}$ due to decompression results in the nucleation of microlites (P3). The dehydration of the melt continues until its water content reaches the solubility curve at that pressure. Experimentally, the rate of crystal nucleation peaks under the influence of increased undercooling as compared to the rate of crystal growth under conditions where a rapid decompression from liquidus conditions to a final pressure is imposed (Cashman 2020). Therefore, near the equilibrium water content, the nucleation rate of the microlites decreases, and the growth of microlites becomes dominant; this is because the increasing rate of $\Delta \mathrm{T}$ starts decreasing when approaching the equilibrium water content. The higher microlite crystallinity and $\mathrm{SiO}_{2}$ contents

tion of the melt is more likely than cooling since degassing 
(a)

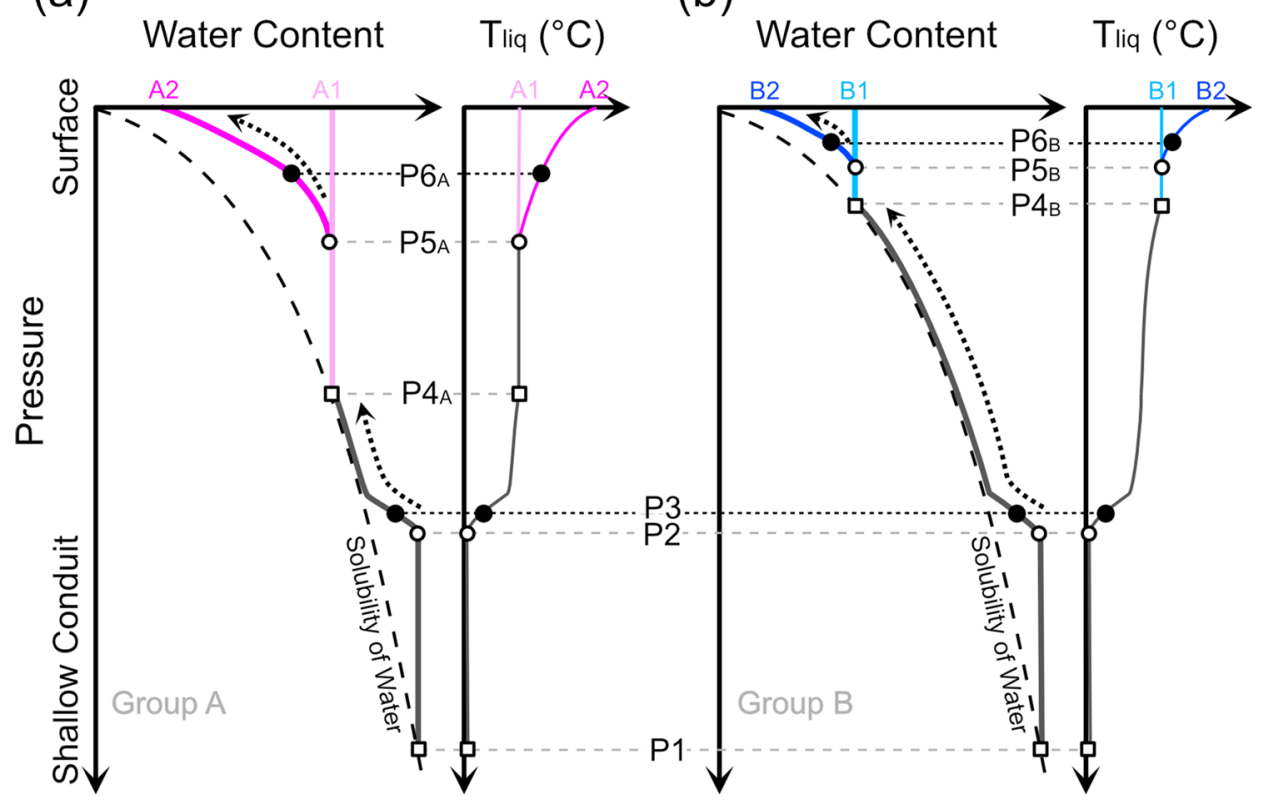

(c)

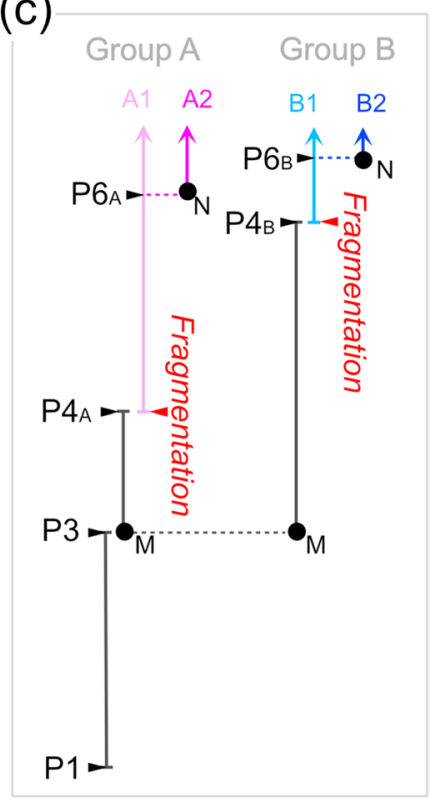

Fig. 8 Schematic illustration showing the timings of saturation of water and nucleation of crystals for magma that formed juvenile particles. Left graphs in (a) and (b) show evolution of water content in magma during decompression ascent (colored lines), and solubility of water in silicate melt (dashed lines). Right graphs in (a) and (b) show the evolution of liquidus temperature of crystals $\left(\mathrm{T}_{\mathrm{liq}}\right)$ depending on the degree of dehydration when the $\mathrm{T}_{\text {liq }}$ at $\mathrm{P}=\mathrm{P} 1$ is set to zero.

of interstitial glass in Group B particles than those in Group A particles indicate a longer duration for microlite crystallization of the former and correspondingly imply a slower decompression rate. The maximum water contents in the interstitial glasses of Group A and B particles $(<1.1 \mathrm{wt} \%$; Table S2) indicate the equilibrium water pressure is less than $10 \mathrm{MPa}$, based on the solubility model of Liu et al. (2005) with the assumption that the temperature range is the same as the 2011 Shinmoedake magma $\left(900-1000{ }^{\circ} \mathrm{C}\right.$; Tomiya et al. 2013). Assuming the density of Group B magma was 2500 $\mathrm{kg} / \mathrm{m}^{3}$, the estimated pressures correspond to the magmastatic pressure at $<408-m$ depth. This implies that microlite crystallization continued from deep part of the conduit to several hundreds of meters from the Earth's surface.

The second step of crystallization occurred for both Group A and Group B. The discontinuous crystal size distribution from microlites to nanolites is attributed to the drastic increase in $\Delta \mathrm{T}$. The processes that drive the increase in $\Delta \mathrm{T}$, such as sudden decompression, rapid cooling, and rise of oxygen fugacity, are thought to be triggered by magma fragmentation in the conduit. Though all these conditions have the potential to affect the crystallization of nanolites, they are difficult to discriminate since crystals are texturally and compositionally similar for the crystallization mechanisms of both decompression
Blank squares, blank circles and filled circles correspond to the point of saturation of water, dehydration of melt and nucleation of crystals, respectively. Dotted arrows show the duration of melt dehydration. A1, A2, B1, and B2 indicate juvenile ash particles produced through each path of decompression. In the graph (c), capital "N" and "M" indicate the starting point for nucleation of nanolites and microlites, respectively

and cooling (Shea and Hammer 2013). In the case of Shinmoedake, we conclude that decompression-induced dehydration after fragmentation mainly affected the nucleation of nanolites, because the rate of liquidus temperature rise is much larger below $\sim 50 \mathrm{MPa}$ than above that pressure (Hammer and Rutherford 2002). When the sudden drop of pressure occurs due to fragmentation, the melt becomes supersaturated with water $\left(\mathrm{P}_{\mathrm{A}}\right.$ and $\left.\mathrm{P} 4_{\mathrm{B}}\right)$, and dehydration of the melt occurs again $\left(\mathrm{P} 5_{\mathrm{A}}\right.$ and $\left.\mathrm{P} 5_{\mathrm{B}}\right)$, the liquidus temperature $\left(\mathrm{T}_{\mathrm{liq}}\right)$ of the crystals increases, and nucleation of nanolites occurs in the same way $\left(\mathrm{P}_{\mathrm{A}}\right.$ and $\left.\mathrm{P} 6_{\mathrm{B}}\right)$. On the other hand, if the melt does not dehydrate efficiently and maintains its water content until quenching, nucleation of nanolites does not occur. This difference in the degree of dehydration produces nanolite-free $\mathrm{A} 1$ and $\mathrm{B} 1$ particles and nanolite-bearing A2 and B2 particles. As noted above, cooling and oxidation of melt could also yield $\Delta \mathrm{T}$ to crystallize nanolites in addition to dehydration (Mujin et al. 2017; Mujin and Nakamura 2020). Therefore, the formation of nanolites can reflect the processes that occurred after fragmentation. 


\section{Correlation with volcanic activities}

Temporal changes to the componentry of the ash samples may be explained by the following magma ascent and degassing processes during the three phases of the 2018 eruption of Shinmoedake (Fig. 9).

The high abundance of potential non-juvenile particles (C1 and $\mathrm{C} 3$ ) in the volcanic ash of Phase 1 indicates that mechanical erosion of the conduit wall was the dominant process of ash production during the beginning phase of the 2018 eruption. Most of these dense and crystalline particles may have been derived from the lava of the 2011 eruption as the eruption vent of the 2018 eruption opened through the 2011 lava that filled the summit crater. The fragments derived from the hydrothermal part of the lava formed $\mathrm{C} 1$ particles, while the fragments from the non-hydrothermally altered part of the lava formed C3 particles. Poorly vesiculated fresh juvenile fragments (B2) are interpreted to be derived from the ascending magma head.

The vesicular juvenile particles (A1 and A2) in the products of Phase 2 indicate the start of the eruption of bubble-bearing magma. Vigorous ash emission continued simultaneously during lava flow extrusion indicating that their origin must be new magma. Tilt change and seismic signals during this phase also support the extrusion of new magma (Yamada et al. 2019). The rapid ascent of the magma resulted in the saturation of water without outgassing, leading to fragmentation by bubble rupturing at a deeper level $\left(\mathrm{P}_{\mathrm{A}}\right)$ and forming vesicular juvenile particles (Group A). The co-existence of vesicular particles (Group A) and poorly vesiculated particles (Group B) in the ash during this phase shows that a part of the magma erupted without outgassing, whereas the other part erupted after outgassing during the conduit ascent toward the near-surface level. The simultaneous eruption of the different types of magma is supported by the surface observation that a continuous ash-laden plume occurred together with effusion of lava from the same vent during this phase. As Group A and Group B particles have been produced by decompression crystallization, co-existence of the different decompression paths could be produced by the spatial variation in the speed of ascending magma in the conduit. Continuous ejection of bubble-bearing magma (Group A) could have entrained a part of the outgassed magma (Group B) in the shallow part of the conduit, thereby

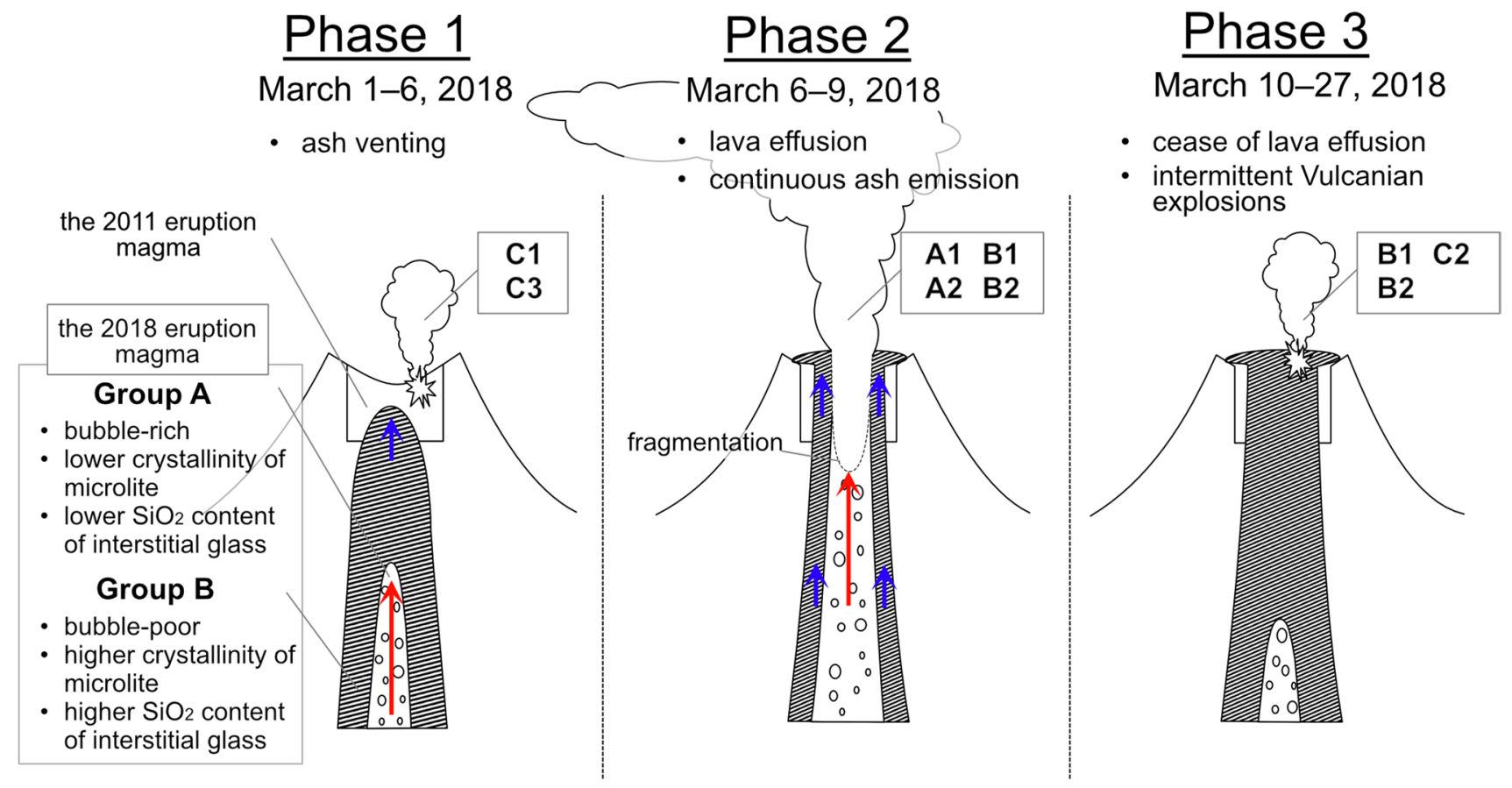

Fig. 9 Schematic illustration showing eruptive processes of the 2018 eruption of Shinmoedake. Phase 1: Non-juvenile particles were sourced from the 2011 lava (C3) and hydrothermal part of the lava (C1), indicating that mechanical erosion of conduit wall was the dominant process of ash production. Phase 2: Bubble-rich magma rapidly ascended from magma chamber to produce vesicular particles (A1 and A2), while degassed magma ascended more slowly with contemporaneous microlite crystallization and produced poorly-vesiculated particles (B1 and B2). Depending on the dehydration of silicate melt during ejection, nucleation of nanolites was enhanced to form black groundmass (A2 and B2). Phase 3: After the cessation of lava supply, dehydration and crystallization of magma progressed in the stagnant lava. Hematite crystals were formed on parts of the lava at the Earth's surface. Vulcanian explosions fragmented and ejected this stagnant lava to form $\mathrm{C} 2$ particles, and produced $\mathrm{B} 1$ and $\mathrm{B} 2$ particles depending on the dehydration at the time of explosion and subsequent quenching 
forming the B1 particles. The rest of the outgassed magma reached the Earth's surface to form lava flow.

The groundmass colors of Group A and Group B particles of Phase 2 vary from colorless (A1 and B1) to black (A2 and B2) due to nanolite crystallinity, thereby indicating the variable dehydration paths of the melt at the time of ejection. Nanolite-free particles (A1 and B1) in the products of Phase 2 indicate the rapid decompression and immediate quenching of magma fragments without effective dehydration, whereas nanolite-bearing particles (A2 and B2) experienced sufficient dehydration after fragmentation. These conditions were probably attained during the continuous and vigorous ejection of ash observed in Phase 2.

The increase in the abundance of poorly vesiculated juvenile particles (B1 and B2) from Phase 2 to Phase 3 indicates that the ash particles in Phase 3 were mainly derived from the slowly ascending outgassed magma (Group B). The complementary decrease of juvenile particles (A1 and A2) was due to the cessation of the extrusion of the volatile-rich magma from the deeper part of the conduit. The cessation of lava flow growth supports the cessation of any new magma supply. After the cessation, stagnation of magma in the shallow conduit enhanced degassing and crystallization of microlites. Subsequently, the outgassed and crystalized magma was fragmented by Vulcanian explosions in Phase 3 to form poorly vesiculated and microlite-rich particles (Group B). Crystallization of nanolites occurred in some parts to form B2 particles due to dehydration after fragmentation at the Vulcanian explosions.

The presence of partly oxidized particles (C2) for the Phase 3 ash samples supports the suggestion of magma stagnation at shallow depths. The particles were not contained in the ash samples before Phase 3, indicating that they were produced after the lava emplacement. A maximum of 4 days had passed from the first observation of lava flow activity (March 6) to the first incidence of $\mathrm{C} 2$ particles in an ash sample (March 10), which represented a sufficient period for the formation of hematite ( $>10 \mathrm{~h}$, at air and at $900{ }^{\circ} \mathrm{C}$ ) (Moriizumi et al. 2009). Therefore, the ash particles of Phase 3 mainly originated from the disruption of the high-temperature lava that erupted after March 6.

\section{Comparison with other cases}

Previous studies showed that variation of ash microtextures reflect shallow level processes from the conduit to the Earth's surface and correlate with the diversities of observed eruption activity (e.g., Wright et al. 2012; Cassidy et al. 2015; Preece et al. 2013). Wright et al. (2012) demonstrated for ash samples from Vulcanian, Strombolian, and violent Strombolian eruptions of Tungurahua volcano's 1999-2006 eruption that the microlite crystallinity was controlled by the magma supply rate. The component proportions of ash particles classified by the crystallinity varied in each sample, suggesting that they may reflect the spatial variation of the ascent speed in the conduit, which is similar to the 2018 Shinmoedake samples. The variation in speed in a conduit is also reported for small Vulcanian eruptions at Volcán de Colima (Cassidy et al. 2015) and the dome-forming eruption of Merapi in 2006 (Preece et al. 2013). These studies indicate that microlite textures are good tracers for the ascent processes of magmas, which rise at variable rates and sometimes stop. Moreover, nanolites can give further constraints on the mechanisms of eruption styles. Mujin and Nakamura (2014) suggested that nanolite mineral assemblages can be attributed mainly to the differences in residence time, cooling, and oxidation near the surface, based on the crystallization sequence of groundmass minerals of sub-Plinian and Vulcanian products of the 2011 Shinmoedake eruption. Since the presence of nanolites affect to the color of erupted materials, by experimentally determining the crystallization conditions of nanolites, colors of erupted materials can be utilized for the evaluation of physicochemical conditions of the magma at near-surface depths. Therefore, the microtextures and componentry of ash are a promising tool for monitoring the temporal change of magma ascent processes and eruption styles at active volcanoes.

\section{Conclusions}

The ash components and the microtextural features from the 2018 eruption of Shinmoedake clearly demonstrate the temporally and spatially complex ascending paths of eruptive andesitic magma, which caused the diverse eruption behavior observed on the surface.

Four types of juvenile ash particles found in the products of the 2018 eruption of Shinmoedake indicate a two-step crystallization process, which is controlled by the decompression, vesiculation, and fragmentation of magma during ascent through the conduit. The nucleation and growth of microlites in the melt were promoted by the decompression-induced dehydration of the melt in the deeper part of the volcanic conduit. The abundance of microlites in the groundmass represents the duration from dehydration to magma fragmentation. The second step formed nanolites in the shallow conduit region by rapid decompression, cooling, and oxidation after fragmentation.

Temporal changes in the composition of volcanic ash particles with the progress of the eruptive activity of Shinmoedake in 2018 demonstrated the change in magma ascending pattern during the eruption. The dominance of non-juvenile particles ( $\mathrm{C} 1$ and $\mathrm{C} 3)$ in Phase 1 indicates the vent opening process due to the erosion of the conduit wall that presumably comprised lava of the 2011 eruption. The simultaneous effusion of lava and continuous ash venting observed in 
Phase 2 was driven by the continuous ascending of magmas with different decompression paths in the conduit, as suggested by the highly vesicular and microlite-poor juvenile particles (A1 and A2) that accompany the microlite-rich poorly vesiculated particles (B1 and B2) in Phase 2. Vulcanian explosions in Phase 3 ejected the fragments of the 2018 lava that were plugging the vent. The dominance of B1 and B2 particles suggests the slow ascent of magma with degassing and microlite crystallization during Phase 3 . The presence of partly oxidized particles $(\mathrm{C} 2)$ also supports the ejection of stagnant lava near the surface.

The study of the 2018 Shinmoedake eruption proves that the microtextures of ash components and their temporal variations are good tracers for the change in magma ascending patterns that control eruption styles. The combination of these analyses is a good tool for reconstructing, monitoring, and predicting past and ongoing eruptive activities.

Supplementary Information The online version contains supplementary material available at https://doi.org/10.1007/s00445-021-01451-6.

Acknowledgments We thank the anonymous reviewers for their thoughtful comments which improved this manuscript. We are grateful to J. Eychenne for her editorial handling. The field survey and collection of ash samples were supported by the members of the Geological Survey of Japan and the Japan Meteorological Agency. We thank Y. Yasuike and Y. Hiroi for help with the digital microscope. We also thank C. Conway for his critical comments and suggestions on the manuscript.

Funding KM was supported by JSPS KAKENHI, Grant Number 19K14820. NG was supported by JSPS KAKENHI, Grant Number $16 \mathrm{H} 06348$

Data availability We can provide data and material if we are contacted.

\section{Declarations}

\section{Conflict of interest Not applicable}

Open Access This article is licensed under a Creative Commons Attribution 4.0 International License, which permits use, sharing, adaptation, distribution and reproduction in any medium or format, as long as you give appropriate credit to the original author(s) and the source, provide a link to the Creative Commons licence, and indicate if changes were made. The images or other third party material in this article are included in the article's Creative Commons licence, unless indicated otherwise in a credit line to the material. If material is not included in the article's Creative Commons licence and your intended use is not permitted by statutory regulation or exceeds the permitted use, you will need to obtain permission directly from the copyright holder. To view a copy of this licence, visit http://creativecommons.org/licenses/by/4.0/.

\section{References}

Brugger CR, Hammer JE (2010) Crystallization kinetics in continuous decompression experiments: implications for interpreting natural magma ascent processes. J Petrol 51:1941-1965

Cáceres F, Wadsworth FB, Scheu B, Colombier M, Maddona C, Cimarelli C, Hess KU, Kaliwoda M, Ruthensteiner B, Dingwell D (2020) Can nanolites enhance eruption explosivity? Geology 48:997-1001

Cashman KV (2020) Crystal size distribution (CSD) analysis of volcanic samples: advances and challenges. Front Earth Sci 8:291

Cassidy M, Cole PD, Hicks KE, Varley NR, Peters N (2015) Rapid and slow: varying magma ascent rates as a mechanism for Vulcanian explosions. Earth Planet Sci Lett 420:73-84

Castro JM, Gardner JE (2008) Did magma ascent rate control the explosive-effusive transition at the Inyo volcanic chain, California? Geology 36:279-282

Chiba T, Oikawa T, Sasaki H, Hirakawa Y, Miyabuchi Y, Nakada S (2018) Topography of the 2018 lava flow from Shinmoedake crater, Kirishima Volcanoes, Kyushu, Japan. Programme and abstracts, the volcanological society of Japan 2018 fall meeting. https://doi.org/10.18940/vsj.2018.0_1 (in Japanese)

D’Oriano C, Bertagnini A, Cioni R, Pompilio M (2014) Identifying recycled ash in basaltic eruptions. Sci Rep 4:5851

Deardorff N, Cashman K (2017) Rapid crystallization during recycling of basaltic andesite tephra: Timescales determined by reheating experiments. Sci Rep 7:46364

Di Genova D, Kolzenburg S, Wiesmaier S, Dallanave E, Neuville DR, Hess KU, Dingwell DB (2017) A compositional tipping point governing the mobilization and eruption style of rhyolitic magma. Nature 552:235-238

Di Genova D, Brooker RA, Mader HM et al (2020) In situ observation of nanolite growth in volcanic melt: a driving force for explosive eruptions. Sci Adv 6:eabb0413

Geospatial Information Authority of Japan (n.d. ) (GSI). Slope gradation map. https://maps.gsi.go.jp/development/ichiran.html. Accessed Apr 2020

Geshi N, Takarada S, Tsutsui T, Mori T, Kobayashi T (2010) Products of the August 222008 eruption of Shinmoedake Volcano, Kirishima Volcanic Group, Japan. Bull Volcanol Soc Jpn 55:5364. https://doi.org/10.18940/kazan.55.1_53 (in Japanese with English abstract)

Geshi N, Miyagi I, Saito G (2017) Estimation of water concentration in volcanic glass using energy dispersal X-ray spectrometry. Bull Volcanol Soc Jpn 62:13-22.https://doi.org/10.18940/kazan.62.1_ 13 (in Japanese with English abstract)

Geshi N, Yamada I, Matsumoto NA, Miyagi I (2020) Accumulation of rhyolite magma and triggers for a caldera-forming eruption of the Aira Caldera, Japan. Bull Volcanol 82:44

Hammer JE, Rutherford MJ (2002) An experimental study of the kinetics of decompression-induced crystallization in silicic melt. J Geophys Res 107:ECV 8-ECV 1-ECV-8-24

Imura R, Kobayashi T (1991) Eruptions of Shinmoedake volcano, Kirishima Volcano Group, in the last 300 years. Bull Volcanol Soc Jpn 36:135-148. https://doi.org/10.18940/kazan.36.2_135 (in Japanese with English abstract)

Imura R, Kobayashi T (2001) Geological map of Kirishima volcano $(1: 50,000)$ Geological Survey of Japan. https://gbank.gsj.jp/volca no/Act_Vol/kirishima/index-e.html

Kozono T, Ueda H, Ozawa T, Koyaguchi T, Fujita E, Tomiya A, Suzuki YJ (2013) Magma discharge variations during the 2011 eruptions of Shinmoe-dake volcano, Japan, revealed by geodetic and satellite observations. Bull Volcanol 75:695 
Leibrandt S, Le Pennec JL (2015) Towards fast and routine analyses of volcanic ash morphometry for eruption surveillance applications. J Volcanol Geotherm Res 297:11-27

Liu Y, Zhang Y, Bejrens $\mathrm{H}$ (2005) Solubility of $\mathrm{H}_{2} \mathrm{O}$ in rhyolitic melts at low pressures and a new empirical model for mixed $\mathrm{H}_{2} \mathrm{O}-\mathrm{CO}_{2}$ solubility in rhyolitic melts. J Volcanol Geotherm Res 143:219-235

Matsumoto K, Nakamura M (2017) Syn-eruptive breakdown of pyrrhotite: a record of magma fragmentation, air entrainment, and oxidation. Contrib Mineral Petrol 172(83)

Matsumoto A, Nakagawa M, Amma-Miyasaka M, Iguchi M (2013) Temporal variations of the petrological features of the juvenile materials during 2006 to 2010 from Showa crater, Sakurajima volcano, Kyushu, Japan. Bull Volcanol Soc Jpn 58:191-212

Miwa T, Toramaru A, Iguchi M (2009) Correlations of volcanic ash texture with explosion earthquakes from vulcanian eruptions at Sakurajima volcano, Japan. J Volcanol Geotherm Res 184:473-486

Miwa T, Geshi N, Shinohara H (2013) Temporal variation in volcanic ash texture during a vulcanian eruption at the Sakurajima volcano, Japan. J Volcanol Geotherm Res 260:80-89

Miyabuchi Y, Hara C (2019) Temporal variations in discharge rate and component characteristics of tephra-fall deposits during the 2014-2015 eruption of Nakadake first crater, Aso Volcano, Japan. Earth Planets Space 71(44)

Miyabuchi Y, Hanada D, Niimi H, Kobayashi T (2013) Stratigraphy, grain-size and component characteristics of the 2011 Shinmoedake eruption deposits, Kirishima Volcano, Japan. J Volcanol Geotherm Res 258:31-46

Moriizumi M, Nakashima S, Okumura S, Yamanoi Y (2009) Colorchange processes of a Plinian pumice and experimental constraints of color-change kinetics in air of an obsidian. Bull Volcanol $71: 1-13$

Mujin M, Nakamura M (2014) A nanolite record of eruption style transition. Geology 42:611-614

Mujin M, Nakamura M (2020) Late-stage groundmass differentiation as a record of magma stagnation, fragmentation, and rewelding. Bull Volcanol 82(48)

Mujin M, Nakamura M, Miyake A (2017) Eruption style and crystal size distributions: crystallization of groundmass nanolites in the 2011 Shinmoedake eruption. Am Mineral 102:2367-2380
Nakada S, Motomura Y (1999) Petrology of the 1991-1995 eruption at Unzen: effusion pulsation and groundmass crystallization. $\mathbf{J}$ Volcanol Geotherm Res 98:173-196

Nakada S, Nagai M, Kaneko T, Nagai M, Kaneko T, Suzuki Y, Maeno F (2013) The outline of the 2011 eruption at Shinmoe-dake (Kirishima), Japan. Earth Planets Space 65:475-488

Okuno M (2002) Chronology of tephra layers in Southern Kyushu, SW Japan, for the last 30,000 years. Daiyonki-kenkyu 41:225-236. https://doi.org/10.4116/jaqua.41.225 (in Japanese with English abstract)

Preece K, Barclay J, Gertisser R, Herd RA (2013) Textural and micropetrological variations in the eruptive products of the 2006 domeforming eruption of Merapi volcano, Indonesia: implications for sub-surface processes. J Volcanol Geotherm Res 261:98-120

Schipper CI, Castro JM, Tuffen H, James MR, How P (2013) Shallow vent architecture during hybrid explosive-effusive activity at Cordón Caulle (Chile, 2011-12): evidence from direct observations and pyroclast textures. J Volcanol Geotherm Res 262:25-37

Shea T, Hammer JE (2013) Kinetics of cooling- and decompressioninduced crystallization in hydrous mafic-intermediate magmas. $\mathrm{J}$ Volcanol Geotherm Res 260:127-145

Taddeucci J, Pompilio M, Scarlato P (2004) Conduit processes during the July-August 2001 explosive activity of Mt. Etna (Italy): inferences from glass chemistry and crystal size distribution of ash particles. J Volcanol Geotherm Res 137:33-54

Tomiya A, Miyagi I, Saito G, Geshi N (2013) Short time scales of magma-mixing processes prior to the 2011 eruption of Shinmoedake volcano, Kirishima volcanic group, Japan. Bull Volcanol 75:750

Wright HMN, Cashman KV, Mothes PA, Hall ML, Ruiz AG, Le Pennec JL (2012) Estimating rates of decompression from textures of erupted ash particles produced by 1999 -2006 eruptions of Tungurahua volcano, Ecuador. Geology 40:619-622

Yamada T, Ueda H, Mori T, Tanada T (2019) Tracing volcanic activity chronology from a multiparameter dataset at Shinmoedake volcano (Kirishima), Japan. J Disaster Res 14:687-700 